\title{
Smutgrass Control in Perennial Grass Pastures ${ }^{\mathbf{1}}$
}

\author{
Brent Sellers, Neha Rana, José Luiz C. S. Dias, and Pratap Devkota²
}

\section{Introduction}

Smutgrass-an invasive bunch grass, native to tropical Asia-is a serious weed of improved perennial grass pastures, roadsides, natural areas, and waste areas in Florida. Results of a survey conducted by the South Florida Beef Forage Program in 2011 indicated that smutgrass ranks as the third most problematic weed species in Florida pastures, behind dogfennel and tropical soda apple. Since then, practices to control tropical soda apple have been widely adopted in Florida; therefore, it is likely that smutgrass has become the most problematic weed species in Florida pastures.

Two smutgrass species are found in Florida-small smutgrass (Sporobolus indicus; Figure 2) and giant smutgrass, which is also known as West Indian dropseed (Sporobolus jacquemontii; Figure 3). Small smutgrass was once the predominant smutgrass species throughout Florida. By the 1990s, however, giant smutgrass had become the most common smutgrass species throughout central and south Florida. Giant smutgrass continues to move northward in Florida.

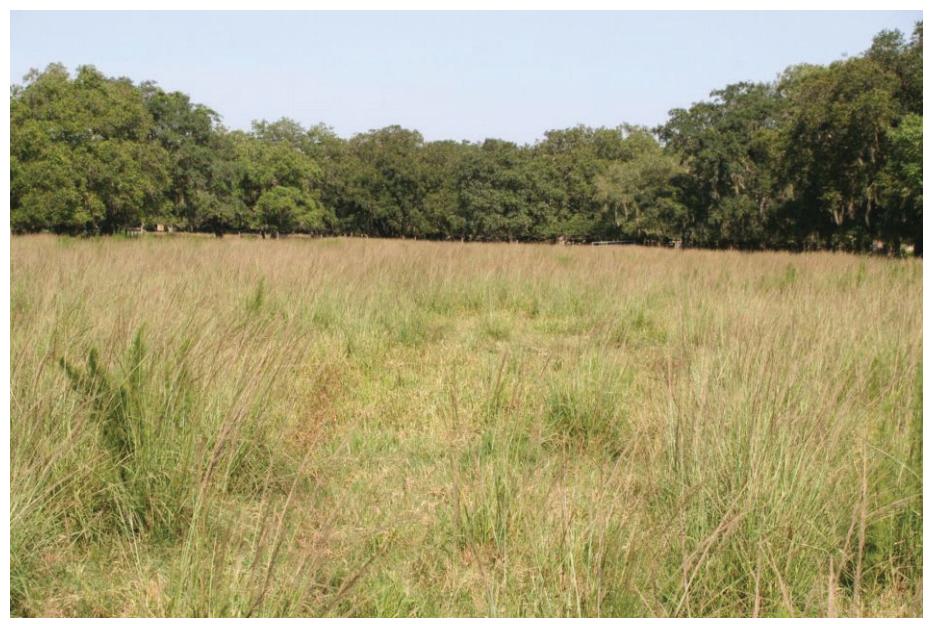

Figure 1. Smutgrass infestations are common in bahiagrass pastures throughout Florida.

Credits: B. Sellers, UF/IFAS

Mature smutgrass plants are unpalatable to livestock, but some grazing of mature smutgrass does occur. New regrowth of smutgrass, which is similar in quality to bahiagrass, can be grazed for two to three weeks after burning or mowing. However, it is difficult to graze cattle on smutgrass due to the need to rotate cattle among smutgrass-infested paddocks so that growth of the smutgrass does not reach a stage where cattle will not graze the plants.

1. This document is SS-AGR-18, one of a series of the Agronomy Department, UF/IFAS Extension. Original publication date February 2000. Revised April 2011, January 2015, February 2018, and October 2020. Visit the EDIS website at https://edis.ifas.ufl.edu for the currently supported version of this publication.

2. Brent Sellers, professor, director, Agronomy Department, UF/IFAS Range Cattle Research and Education Center; Neha Rana, former graduate research assistant, Agronomy Department, UF/IFAS RCREC; José Luiz C. S. Dias, former graduate research assistant, Agronomy Department, UF/IFAS RCREC; and Pratap Devkota, assistant professor, Agronomy Department, UF/IFAS West Florida Research and Education Center; UF/IFAS Extension, Gainesville, FL 32611. Original authors included M. B. Adjei, associate professor, and P. Mislevy, professor, both formerly of the Agronomy Department, UF/IFAS Range Cattle Research and Education Center, Ona, FL.

The use of trade names in this publication is solely for the purpose of providing specific information. UF/IFAS does not guarantee or warranty the products named, and references to them in this publication do not signify our approval to the exclusion of other products of suitable composition. Use herbicides safely. Read and follow directions on the manufacturer's label.

The Institute of Food and Agricultural Sciences (IFAS) is an Equal Opportunity Institution authorized to provide research, educational information and other services

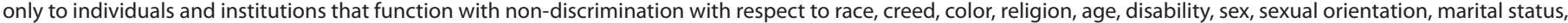
national origin, political opinions or affiliations. For more information on obtaining other UF/IFAS Extension publications, contact your county's UF/IFAS Extension office. U.S. Department of Agriculture, UF/IFAS Extension Service, University of Florida, IFAS, Florida A \& M University Cooperative Extension Program, and Boards of County Commissioners Cooperating. Nick T. Place, dean for UF/IFAS Extension. 


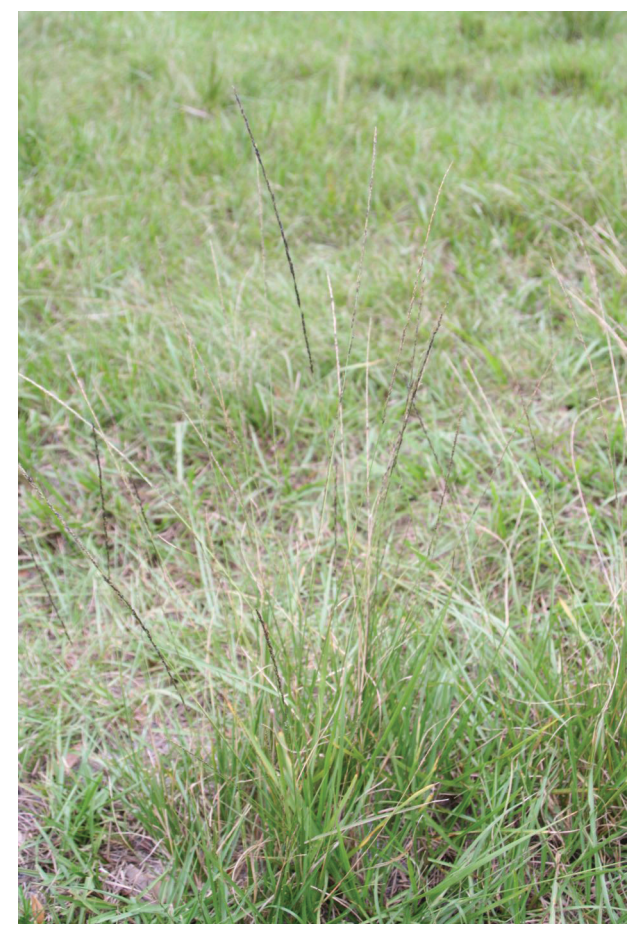

Figure 2. Small smutgrass, once the most troublesome smutgrass species in Florida, is still found throughout the state.

Credits: B. Sellers, UF/IFAS

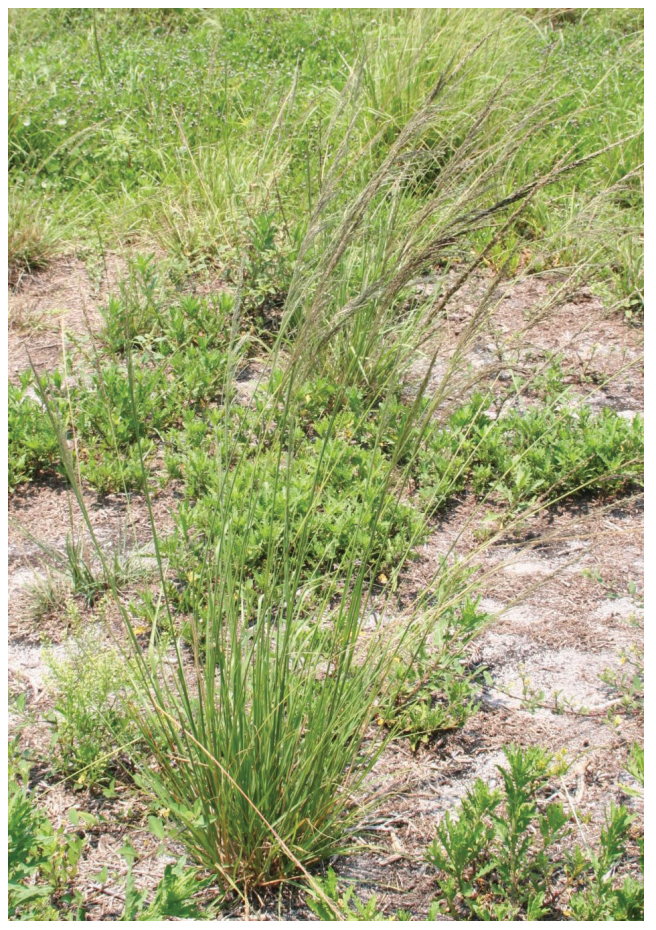

Figure 3. Giant smutgrass first became a problem in south Florida and is spreading north through the state. In central and south Florida, giant smutgrass is more problematic than small smutgrass. Credits: B. Sellers, UF/IFAS

\section{Biology}

Both smutgrass species-small and giant-are perennial bunch grasses. Average bunch size of small smutgrass is approximately $8-10$ inches in diameter while giant smutgrass diameter is approximately $12-18$ inches.
Small smutgrass has a compact seedhead (Figure 4) with the panicle branches touching the panicle. The small smutgrass seedhead is almost always infected with a black fungus. Small smutgrass plants produce approximately 1,400 seeds per seedhead and 45,000 seeds per plant.

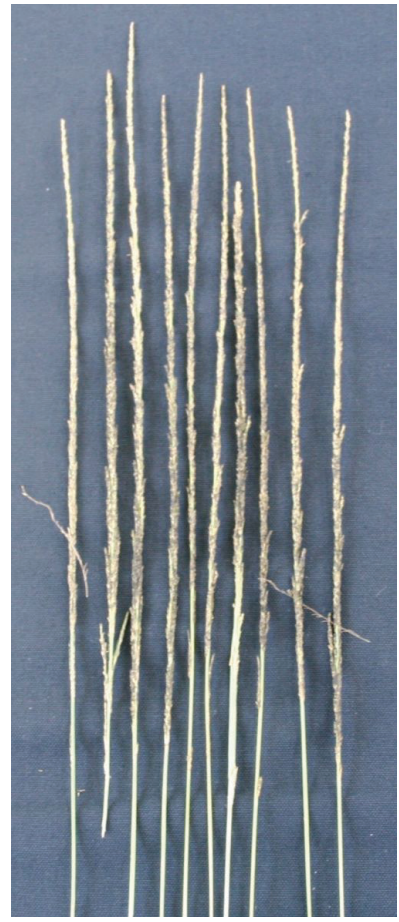

Figure 4. Small smutgrass seedheads are appressed near the raceme, giving the seedhead a cylindrical appearance.

Credits: B. Sellers, UF/IFAS

In contrast, giant smutgrass has an open seedhead with panicle branches directed somewhat upward (Figure 5). The seedhead of giant smutgrass is usually not infected with the black fungus, but sometimes the fungus is present. Little information exists about seed production of giant smutgrass, but some indications suggest this plant may be a more prolific seed producer than small smutgrass.

Seed production of both species occurs throughout the growing season, and new seedheads are produced shortly after mowing or burning. The seeds, which are red to orange in color, remain attached to seedheads for some time after maturing. They adhere to livestock and machinery and also travel via water and wind. Natural seed germination has been shown to average less than $9 \%$, and seed are thought to remain viable in the soil for at least two years. 


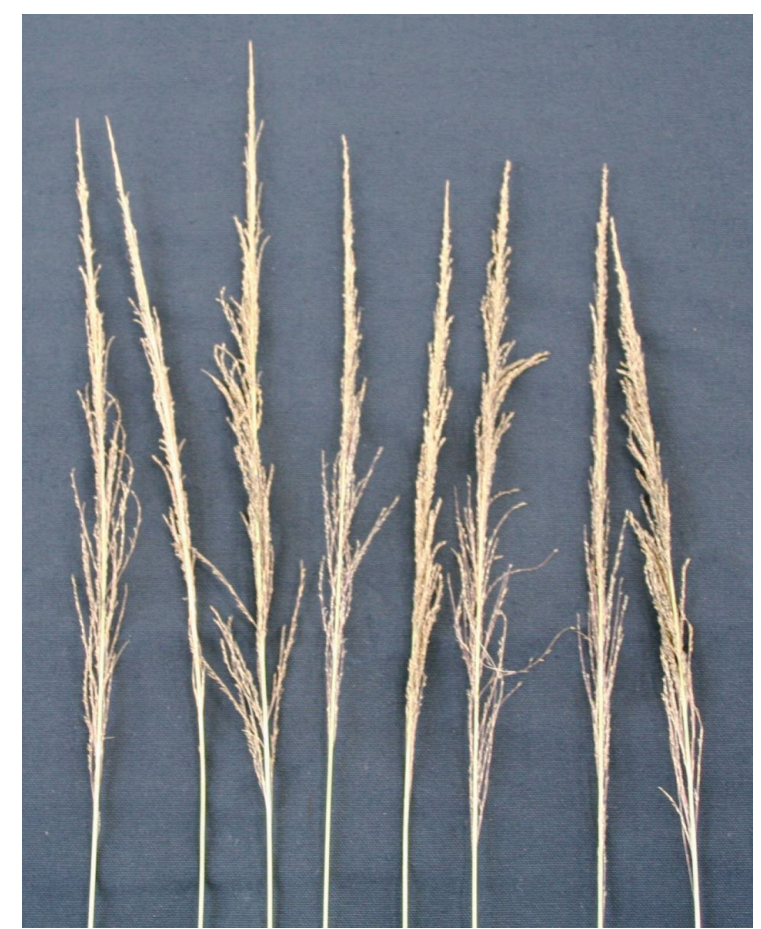

Figure 5. Giant smutgrass seedheads are open and generally not infested with the black smut fungus that typically infests small smutgrass.

Credits: B. Sellers, UF/IFAS

\section{Control}

Because smutgrass species are nearly indistinguishable without seedheads, we recommend that giant and small smutgrass be treated similarly. Both species are generally unpalatable to cattle.

Cultural practices to control smutgrass species have not been successful. Mowing decreases the diameter of the clumps, but often results in increased density. Burning is thought to increase the germination of seeds in the soil seed bank. However, both burning and mowing allow for approximately two to three weeks of grazing. Smutgrass forage quality during this two- to three-week window is often equal to or slightly greater than bahiagrass.

Chemical control of smutgrass includes applying hexazinone at 0.5-1.0 lb/acre (Velpar/Tide Hexazinone at 1-2 qt/acre; Velossa at 0.84-1.67 qt/acre) to small and giant smutgrass. Use lower rates when a multi-year approach is planned. Even when the highest rate is used, a second application during the following growing season may be warranted. A surfactant may be added to Velpar (Velossa contains a surfactant), but recent research has indicated that a surfactant is not necessary because the herbicide works primarily by root uptake. Mowing or burning smutgrass prior to hexazinone application does not increase control. Hexazinone should be applied from June through
September, when rainfall is typically sufficient to move the herbicide into the root zone for uptake. There is little foliar activity from hexazinone on smutgrass. If rainfall does not occur within one week after application, the herbicide treatment will likely fail. The same can be said for rainfall that exceeds 3 inches within one week after application. There are no grazing restrictions for hexazinone if the application rate is below $1.13 \mathrm{lb} /$ acre. However, there is a 38-day haying restriction.

Hexazinone is a highly effective herbicide, but it is also expensive. Experiments were recently conducted to determine when hexazinone should be applied to maximize smutgrass control and return on the herbicide investment. An economic analysis indicated that hexazinone should not be applied until smutgrass density is approximately $50 \%$ of the area of a pasture. Applications of this herbicide prior to this level of infestation will not result in enough additional bahiagrass biomass (i.e., ability to increase stocking rate) to justify the cost of application. However, in terms of preventing smutgrass infestation, it may be economically justifiable to spray highly infested areas of a pasture, even before $50 \%$ of the entire pasture is infested.

Oak trees are extremely sensitive to hexazinone. Be sure to stay at least $100 \mathrm{ft}$ away from oak trees while making applications. If smutgrass is present under or near oak trees, spot applications of $3 \%$ glyphosate are effective.

\section{Forage Grass Tolerance}

Bahiagrass will turn slightly yellow about 15-20 days after spraying with hexazinone at the recommended rates. However, bahiagrass will recover and turn dark green within about 40 days. This green color will be darker than the non-treated pastures. Bermudagrass will turn yellow with some necrosis for approximately 30 days before new green growth occurs.

\section{Recommendations}

\section{General}

- Do not apply hexazinone within 100 feet of oak trees because application within this range may cause tree death.

- Read the Velpar, Tide Hexazinone, or Velossa label for complete instructions on reapplication interval, safety, grazing, and haying restrictions.

- Cattle may graze treated pastures if applications are less than 4.5 pt/acre Velpar or Tide Hexazinone and 3.75 pt/ acre Velossa. 
- To improve the chance of economic gains from hexazinone application, smutgrass infestation should be approximately $50 \%$ of the pasture.

- If the initial smutgrass density covers more than $80 \%$ of the pasture area (i.e., if 8 out of 10 regular steps touch the base of smutgrass plants), complete renovation of the pasture should be considered.

\section{Bahiagrass/Bermudagrass Pastures}

- Graze pasture in the spring until the beginning of the rainy season.

- Apply 2.0 qt/acre Velpar/Tide Hexazinone (1.67 qt/acre Velossa) during the summer rainy season, but no later than the end of September. Apply when plants are actively growing and rainfall is dependable and consistent.

Retreatment the following year may be necessary.

- An alternative to applying $2.0 \mathrm{qt} / \mathrm{A}$ Velpar/Tide Hexazinone is to plan on at least a two-year application program by applying 1.0-1.5 qt/A in the first year followed by 1.0 $\mathrm{qt} / \mathrm{A}$ in the second year from the end of June through the end of September. A third year of treatment may be necessary, depending on environmental conditions before and after application.

- Fertilization after hexazinone application will increase forage production and allow the desirable grass to quickly fill the open areas created by dying smutgrass.

\section{Floralta Limpograss}

- Hexazinone is not currently labeled for smutgrass control in limpograss.

\section{Stargrass}

- Hexazinone is not currently labeled for smutgrass control in stargrass.

\section{Mulato}

- Hexazinone is not currently labeled for smutgrass control in Mulato because it will result in severe plant injury. DO NOT USE.

\section{Weed Wiper}

The use of a weed wiper is an additional method to manage smutgrass infestations. The bulk of our research has been conducted mid-summer using both glyphosate and hexazinone on mowed and non-mowed smutgrass. In general, hexazinone was the most effective at concentrations of $30 \%$ or $60 \% \mathrm{v} / \mathrm{v}$; however, none of the hexazinone labels lists the weed wiper as an application method. Furthermore, this high-mix ratio of hexazinone in water may not be economical if treating large areas. Glyphosate was effective at concentrations of $35 \%$ and $70 \% \mathrm{v} / \mathrm{v}$. Smutgrass control was greater than $90 \%$ in additional demonstration trials using $10 \% \mathrm{v} / \mathrm{v}$ in late spring/early summer, when short, desirable species allowed more than $50 \%$ of the smutgrass clump to be exposed.

Providing a recommendation for a concentration in the weed wiper is nearly impossible due to the various results obtained with different concentrations, different wipers, and at different times of the year. However, it is possible to provide some basic information that will increase the likelihood of success. Keeping the wiper wet with herbicide solution is of primary importance. If the wiper stays sufficiently wet, solutions with lower herbicide concentrations can be effective. Wipe target plants in two directions; smutgrass wiped in only one direction was not controlled at any solution concentration in our research. Finally, practice in a small area to refine your techniques for keeping the wiper wet.

\section{Pasture Renovation}

Consider pasture renovation in highly infested bahiagrass pastures where smutgrass groundcover exceeds $70 \%-80 \%$. Spray the entire pasture with $4 \mathrm{qt} / \mathrm{acre}$ glyphosate and begin tillage practices no earlier than three weeks after application. Repeated tillage will destroy newly emerged smutgrass and aid in depleting the soil seedbank. The final seedbed should be a smooth, flat surface devoid of vegetation. For additional information on bahiagrass varieties and seeding rates, see EDIS publications SS-AGR-332, Bahiagrass (Paspalum notatum Flueggé): Overview and Pasture Management (https://edis.ifas.ufl.edu/ag342), and SS-AGR-161, Forage Planting and Establishment Methods on Prepared Seedbed (https://edis.ifas.ufl.edu/ag107).

Even with repeated tillage following glyphosate application, smutgrass will likely emerge with bahiagrass, and smutgrass seedheads will be present by the following summer growing season. One year after seeding and during the rainy season, apply $0.5 \mathrm{lb} /$ acre hexazinone (Velpar/Tide Hexazinone at $32 \mathrm{oz} /$ acre or Velossa at $27 \mathrm{oz} /$ acre). According to recent research, hexazinone application one year after seeding resulted in more than $90 \%$ control of smutgrass for two years after application. Nevertheless, the newly renovated pasture should be scouted the following year. A second application of hexazinone may be warranted if smutgrass densities remain high. 